\title{
Svenska Fysikersamfundet
}

(Swedish Physical Society)

\section{KOSMOS}

\section{System Johansson}

\section{Torsten Althin}

Kungliga Tekniska Högskolan, Stockholm, Sverige (Sweden)

Ladda hem en pdf

(Get pdf) 